\title{
Chiral heterocyclic ligands. XIV. Control of directionality in silver coordination polymers through ligand design $\dagger$
}

\author{
Christopher M. Fitchett ${ }^{a}$ and Peter J. Steel $* a$ \\ Receipt/Acceptance Data [DO NOT ALTER/DELETE THIS TEXT] \\ ${ }_{5}$ Publication data [DO NOT ALTER/DELETE THIS TEXT] \\ DOI: 10.1039/b000000x [DO NOT ALTER/DELETE THIS TEXT]
}

Four $\mathrm{C}_{2}$-symmetric homochiral ligands derived from (+)camphor are shown to produce linear chain and ladder silver coordination polymers wherein the directionality and 10 polarisation can be controlled by subtle differences in ligand design.

There has been much recent interest in the study of linear 1-D silver coordination polymers involving bridging N-heterocyclic ligands. ${ }^{1}$ Coordination polymers ${ }^{2}$ are now recognized as offering 15 considerable potential as functional materials, ${ }^{3}$ such as in the area of non-linear optics (NLO). ${ }^{4}$ An important requirement for these properties is that the material be non-centrosymmetric and we believe that the simplest approach to the synthesis of noncentrosymmetric coordination polymers is to employ chiral 20 bridging ligands. ${ }^{5}$ Furthermore, it has been stated that such effects can be amplified by the additional polarisation associated with directionality in the chain. ${ }^{6}$

We have previously shown ${ }^{7}$ that the homochiral $\mathrm{C}_{2}$-symmetric ligand $\mathbf{1}$ (scheme 1), consisting of a central pyrazine ring with two 25 fused bornane groups, readily forms a linear 1-D silver coordination polymer. However, the symmetry of $\mathbf{1}$ is such that the resulting polymer, although chiral, is non-directional (Figure 1(a)). This is because the $\mathrm{C}_{2}$-axis within the ligand is perpendicular to the plane of the central pyrazine ring, making the two nitrogen donors 30 equivalent. As a consequence this coordination polymer is identical when viewed from either end of the chain. We now report the use of an isomeric chiral ligand $\mathbf{2}$ for the construction of a directional silver coordination polymer and the extension of this design strategy to a new class of tetradentate chiral ligand, viz $\mathbf{3}$ and $\mathbf{4}$, for 35 the rational construction of chiral ladder polymers.<smiles>CC12CCC(c3nc4c(nc31)C1CCC4(C)C1(C)C)C2(C)C</smiles>

1

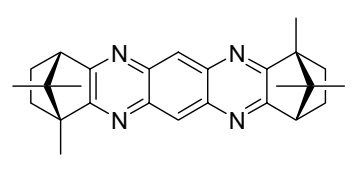

3

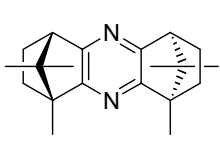

2

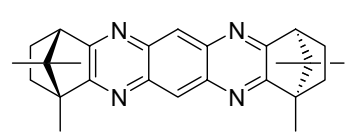

4

Scheme 1

\footnotetext{
${ }^{a}$ Department of Chemistry, College of Science, University of Canterbury, Christchurch 8020, New Zealand. Fax: $++64-3-3642110 ;$ Tel: $++64-3-$ 3642432'E-mail: peter.steel@canterbury.ac.nz

$\uparrow$ Electronic Supplementary Information (ESI) available: X-ray crystallographic data for compounds $\mathbf{2}, \mathbf{5}$ and $\mathbf{6}$. See http://dx.doi.org/10.1039/b000000x/
}

This journal is (c) The Royal Society of Chemistry [year]

(a)

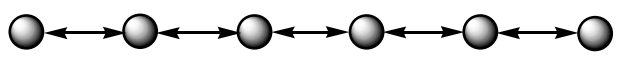

(b)



(c)

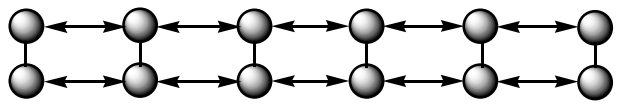

(d)

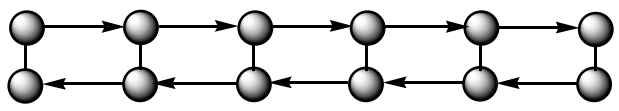

(e)



Fig. 1. Types of 1-D coordination polymers: (a) non-directional linear chain (b) directional linear chain (c) non-directional ladder (d) bidirectional ladder (c) unidirectional ladder.

Ligand 2 has previously been prepared, ${ }^{8}$ in very low yield, from 3 -aminocamphor but has not been used as a ligand in coordination chemistry. We prepared it from $(1 \mathrm{R})-(+)$-camphor by conversion to camphorquinone and subsequent reaction with ammonium acetate 40 and hexamethylenetetramine in acetic acid. This gave a 9:1 mixture of 2 and 1, which were separated by column chromatography $\$$. In order to confirm the structure of this isomer an X-ray structure determination of the free ligand was carried out (Figure 2). It crystallizes in the tetragonal space group $\mathrm{P}_{1}{ }_{1}{ }_{1} 2$ and lies on $\mathrm{C}_{2^{-}}$ 45 axis that passes through the two nitrogen atoms $\uparrow$. This ligand differs from $\mathbf{1}$ in that the two nitrogen donors are now very different; N4 has a much less hindered environment than N1, which is shielded by two adjacent bridgehead methyl groups.

Reaction of 2 with silver(I) nitrate in 1:1 acetone:methanol

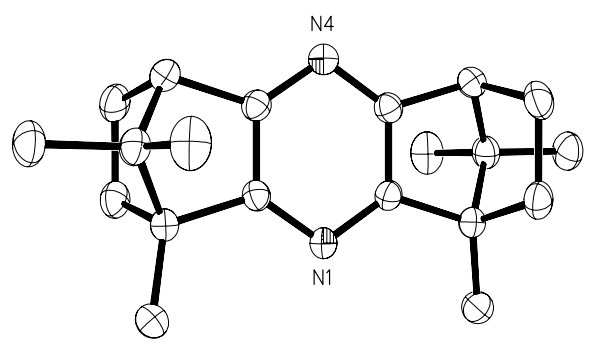

Fig. 2 X-Ray structure of ligand 2. The hydrogen atoms are not shown. 
50 furnished a crystalline complex (5) in moderate yield§. This compound crystallizes in the orthorhombic space group $\mathrm{P} 2{ }_{1} 2_{1} 2_{1}$ with two bridging ligands, two silver atoms, two nitrate counterions and two disordered water molecules in the asymmetric unit Figure 3 shows a view of a section of the resulting coordination ${ }_{55}$ polymer, which propagates along the $b$ axis of the unit cell. Within this structure ligand $\mathbf{2}$ faithfully assembles in a head-to-tail manner, bridging two silver atoms which have near-linear two-coordinate geometries. The slight deviations from linearity [N-Ag-N angles of $164.5(2)^{\circ}$ and $167.5(2)^{\circ}$ ] are in response to ${ }^{9}$ additional weak 60 interactions with nearby nitrate oxygen atoms $[\mathrm{Ag} \cdots \mathrm{O}$ distances of 2.682(3) and 2.678(3) $\AA$ ]. The key feature of this structure is that, unlike the corresponding non-directional coordination polymer produced from ligand $\mathbf{1}$, this is a directional polymer (Figure (1b)), within which all ligand bridges are aligned in the same direction 65 and hence has additional polarisation. This difference is a direct result of the different orientations of the $\mathrm{C}_{2}$-axes within the ligands themselves.

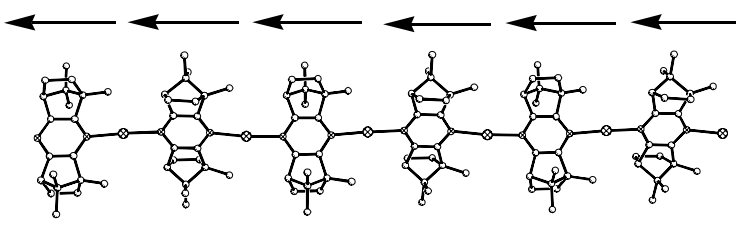

Fig. 3 Perspective view of a section of the unidirectional polymeric chain structure of $\mathbf{5}$, showing the head-to-tail alignment of the bridging ligands. The hydrogen atoms, nitrate counterions, and disordered water solvate molecules have been omitted for clarity.

Chiral coordination polymers of this type are rare. For example, a search of the May 2006 version of the Cambridge Structural 70 Database $^{10}$ located 5619 silver compounds of which 2275 were polymeric, but only 229 of these exist in Sohncke (chiral) space groups. The majority of these are conglomerates resulting from spontaneous resolution of polymers derived from achiral components and only 48 contain homochiral ligands. Half of these

75 are $\mathrm{C}_{2}$-symmetric ligands and therefore lead to non-directional coordination polymers. Of the remaining 24 complexes derived from unsymmetrical bridging ligands only 7 are 1 -D polymers, six being derived from amino acids ${ }^{11}$ and one from (-)-nicotine. ${ }^{12}$ Thus the present directional polymer exploits the known propensity of 80 pyrazine derivatives to form 1-D silver polymers ${ }^{9}$ in combination with the chirality resulting from the fused camphor groups. However, it should be pointed out that although each polymer chain is unidirectional, adjacent chains are anti-parallel due to the orthogonal $2_{1}$-screw axes within this space group.

85 We next turned our attention to the design of a completely new class of bridging ligand, based on a 1,4,5,8-tetraazaanthracene core, for the construction of ladder polymers. Surprisingly, 1,4,5,8tetraazaanthracene has not been employed as a bridging ligand. The ligands, 3 and 4, were prepared by reaction of camphorquinone 90 with 1,2,4,5-tetraamino benzene. This produced a 1:1 mixture of the two isomers which have two bornane units fused to a central 1,4,5,8-tetraazaanthracene core. Separation of these proved problematic, but was finally achieved after repeated column chromatography and recrystallization $\downarrow$. These two isomeric ligands 95 have a similar relationship to the simpler ligands $\mathbf{1}$ and $\mathbf{2}$, in that ligand $\mathbf{3}$ has a $\mathrm{C}_{2}$-axis perpendicular to the plane of the central ring, whereas ligand 4 has the $\mathrm{C}_{2}$-axis lying in the plane of the ring.

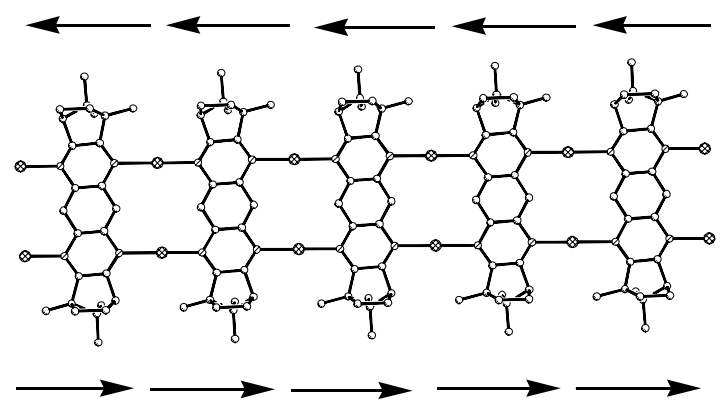

Fig. 4 Perspective view of a section of the bidirectional ladder polymer 6 . The hydrogen atoms, nitrate counterions and solvate molecules have been omitted for clarity.

Reaction of ligand 3 with silver nitrate in acetone:methanol solution produced a crystalline product (6) in $51 \%$ yield $\S$, the 100 structure of which was determined by X-ray crystallography $\%$. It crystallizes in the orthorhombic space group $\mathrm{P} 2{ }_{1} 2{ }_{1} 2$ with half a molecule of the bridging ligand $\mathbf{3}$, a silver atom, a nitrate counterion and a disordered water molecule in the asymmetric unit. ${ }^{13}$ Figure 4 shows a view of the structure which propagates 105 along the $a$ axis of the unit cell with a crystallographic $\mathrm{C}_{2}$-axis passing through the centre of the ligand. The ligand $\mathbf{3}$ acts as a tetradentate ligand bridging four silver atoms, each of which has near-linear two-coordinate geometry. This leads to a ladder structure with the silver atoms providing the sides of the ladder and 110 ligand 3 providing the rungs. More specifically, it is a bidirectional ladder (Figure 1(d)) which again presents the same structure when viewed from either end.

A similar reaction of ligand $\mathbf{4}$ with silver nitrate produced a product (7) in 58\% yield§. Elemental analysis revealed that this 115 also has $\mathrm{M}_{2} \mathrm{~L}$ stoichiometry. However, despite numerous attempts, this compound failed to provide crystals suitable for crystallographic investigation. Nevertheless, we are confident that the structure of this compound has a unidirectional ladder structure (Figure 2(e)).

120 In conclusion, we have shown that it is possible to control the directionality and polarisation within silver linear coordination polymers through subtle changes in ligand design. Specifically, reorientation of a $\mathrm{C}_{2}$ axis of symmetry within a ligand can result in a change from a non-directional to a unidirectional polymer.

125

We thank the Royal Society of New Zealand for funding through the Marsden Fund and a James Cook Research Fellowship.

\section{Notes and references}

$\ddagger$ Preparations of ligands: 2: Camphorquinone (0.83 g $5.0 \mathrm{mmol})$, 130 ammonium acetate $(3.97 \mathrm{~g}, 51.5 \mathrm{mmol})$ and hexamethylenetetramine $(7.01 \mathrm{~g}, 50.0 \mathrm{mmol})$ were refluxed in dry acetic acid under nitrogen for 20 hr. The mixture was added to water $(100 \mathrm{ml})$, neutralized $(\mathrm{NaOH})$ and extracted with ether $(2 \times 75 \mathrm{ml})$. The organic phase was washed with water $(50 \mathrm{ml})$, dried $\left(\mathrm{Na}_{2} \mathrm{SO}_{4}\right)$ and the solvent evaporated in vacuo to give 135 a yellow solid. Flash chromatography (10 g silica, 1:1 pet ether/EtOAc) and recrystallization form 1:1 acetone/water gave $\mathbf{2}$ as a white crystalline solid. Yield $0.16 \mathrm{~g}(22 \%)$. M.p. $202-203^{\circ} \mathrm{C}$ (lit. ${ }^{8} 204-205^{\circ} \mathrm{C}$ ). ${ }^{1} \mathrm{H}$ NMR $\left(500 \mathrm{MHz}, \mathrm{CDCl}_{3}\right): \delta 2.85(2 \mathrm{H}, \mathrm{d}, \mathrm{H} 4), 2.15\left(2 \mathrm{H}, \mathrm{m}, \mathrm{H} 6_{\mathrm{exo}}\right), 1.88(2 \mathrm{H}, \mathrm{m}$, $\left.\mathrm{H} 5_{\text {exo }}\right), 1.32(6 \mathrm{H}, \mathrm{s}, 1-\mathrm{Me}), 1.21$ (4H, dd, $\left.\mathrm{H} 5_{\text {endo }}, \mathrm{H} 6_{\text {endo }}\right), 0.98$ (6H, s, 7140 anti-Me), $0.54(6 \mathrm{H}, \mathrm{s}, 7-$ syn-Me). 3 and 4: 1,2,4,5-Tetraaminobenzene $(2.11 \mathrm{~g}, 7.4 \mathrm{mmol})$, camphorquinone $(2.35 \mathrm{~g}, 14.1 \mathrm{mmol})$ and sodium acetate $(2.62 \mathrm{~g} 32 \mathrm{mmol})$ were refluxed in dry ethanol under argon for 40 
hr. The ethanol was evaporated in vacuo and the red solid extracted with $\mathrm{CHCl}_{3}(2 \times 75 \mathrm{ml})$. This was washed $(2 \times 50 \mathrm{ml})$, dried $\left(\mathrm{Na}_{2} \mathrm{SO}_{4}\right)$ and the 145 solvent evaporated in vacuo. The yellow solid was chromatographed $(20$ $\mathrm{g}$ silica, $1: 1$ pet ether/EtOAc) to remove unreacted camphorquinone. The remaining off white solid was a 1:1 mixture of 3 and $\mathbf{4}$. Yield $0.99 \mathrm{~g}$. These were separated by repeated chromatography $(20 \mathrm{~g}$ silica $3: 1$ pet ether/EtOAc) to give $\mathbf{3}$ and $\mathbf{4}$ as white solids which were recrystallized

150 from 1:1 pet ether/ethyl acetate. 3: Yield $0.41 \mathrm{~g}(15 \%)$. M.p. $>300{ }^{\circ} \mathrm{C} .{ }^{1} \mathrm{H}$ $\operatorname{NMR}\left(500 \mathrm{MHz}, \mathrm{CDCl}_{3}\right): \delta 8.65(2 \mathrm{H}, \mathrm{s}, \mathrm{H} 9), 3.10(2 \mathrm{H}, \mathrm{d}, \mathrm{H} 4), 2.34(2 \mathrm{H}$, $\left.\mathrm{m}, \mathrm{H} 6_{\text {exo }}\right), 2.09$ ( $\left.2 \mathrm{H}, \mathrm{m}, \mathrm{H} 5_{\text {exo }}\right), 1.48$ (4H, dd, $\left.\mathrm{H} 5_{\text {endo }}, \mathrm{H} 6_{\text {endo }}\right), 1.47(6 \mathrm{H}, \mathrm{s}$, 1-Me), 1.15 (6H, s, 7-anti-Me), 0.67 (6H, s, 7-syn-Me). Anal. Found: C, 78.36; H, 7.59; N, 14.06. Calc. for $\mathrm{C}_{26} \mathrm{H}_{30} \mathrm{~N}_{4}$ : C, $78.34 ; \mathrm{H}, 7.37 ; \mathrm{N}, 14.04$ 155 EI-MS: Found $\mathrm{M}^{+} 398.2480, \mathrm{C}_{26} \mathrm{H}_{30} \mathrm{~N}_{4}$ requires $\mathrm{M}^{+} 398.2471 ; 4$ : Yield $0.39 \mathrm{~g}(14 \%)$. M.p. $>300^{\circ} \mathrm{C} .{ }^{1} \mathrm{H}$ NMR $\left(500 \mathrm{MHz}, \mathrm{CDCl}_{3}\right): \delta 8.70(1 \mathrm{H}, \mathrm{s}$, H8), $8.60(1 \mathrm{H}, \mathrm{s}, \mathrm{H} 9), 3.11(2 \mathrm{H}, \mathrm{d}, \mathrm{H} 4), 2.34\left(2 \mathrm{H}, \mathrm{m}, \mathrm{H6} \mathrm{exo}_{\mathrm{xo}}\right), 2.09(2 \mathrm{H}, \mathrm{m}$, $\left.\mathrm{H} 5_{\text {exo }}\right), 1.48$ (4H, dd, $\left.\mathrm{H} 5_{\text {endo }}, \mathrm{H} 6_{\text {endo }}\right), 1.47$ (6H, s, 1-Me), 1.15 (6H, s, 7anti-Me), $0.66(6 \mathrm{H}, \mathrm{s}, 7-s y n-\mathrm{Me})$. Anal. Found: C, 78.32; H, 7.62; N, 160 14.12. Calc. for $\mathrm{C}_{26} \mathrm{H}_{30} \mathrm{~N}_{4}$ : C, $78.34 ; \mathrm{H}, 7.37 ; \mathrm{N}, 14.06$. EI-MS: Found $\mathrm{M}^{+}$ 398.2463, $\mathrm{C}_{26} \mathrm{H}_{30} \mathrm{~N}_{4}$ requires $\mathrm{M}^{+} 398.2471$.

$\S$ Preparations of complexes: 5: Reaction of 2 (14.6 $\mathrm{mg}, 0.05 \mathrm{mmol})$ dissolved in hot acetone with silver nitrate $(17.3 \mathrm{mg}, 0.10 \mathrm{mmol})$ 165 dissolved in hot methanol gave a colourless solution. Crystals suitable for X-ray diffraction were obtained on cooling. Yield $8.9 \mathrm{mg}$ (30\%). M.p. $>250^{\circ} \mathrm{C}$ (dec.). Anal. Found: C, 49.60; H, 6.24; N, 8.68. Calc. for $\mathrm{C}_{20} \mathrm{H}_{28} \mathrm{~N}_{3} \mathrm{O}_{3}$ Ag. $\mathrm{H}_{2} \mathrm{O}$ : C, 50.00; H, 6.40; N, 8.29. 6: Reaction of 3 (19.9 $\mathrm{mg}, 0.05 \mathrm{mmol})$ dissolved in hot acetone with silver nitrate $(17.5 \mathrm{mg}, 0.10$ $170 \mathrm{mmol}$ ) dissolved in hot methanol gave a colourless solution. Crystals suitable for X-ray diffraction were obtained on standing. Yield $18.9 \mathrm{mg}$ (51\%). M.p. $>200^{\circ} \mathrm{C}$ (dec.). Anal. Found: C, 41.98; H, 4.19; N, 11.28. Calc. for $\mathrm{C}_{26} \mathrm{H}_{30} \mathrm{~N}_{6} \mathrm{O}_{6} \mathrm{Ag}_{2}$ : C, 42.30; H, 4.10; N, 11.38; 7: Reaction of 4 (20.0 $\mathrm{mg}, 0.05 \mathrm{mmol})$ dissolved in hot acetone with silver nitrate $(17.2$

$175 \mathrm{mg}, 0.10 \mathrm{mmol}$ ) dissolved in hot methanol gave a colourless solution. A colourless precipitate appeared after standing for 5 mins. Yield $21.5 \mathrm{mg}$ (58\%). M.p. $>250^{\circ} \mathrm{C}$ (dec.). Anal. Found: C, 41.51; H, 4.22; N, 11.19 . Calc. for $\mathrm{C}_{26} \mathrm{H}_{30} \mathrm{~N}_{6} \mathrm{O}_{6} \mathrm{Ag}_{2} \cdot \mathrm{H}_{2} \mathrm{O}: \mathrm{C}, 41.29 ; \mathrm{H}, 4.26 ; \mathrm{N}, 11.11$.

180 Summary of X-ray details: 2: $\mathrm{C}_{20} \mathrm{H}_{28} \mathrm{~N}_{2}$, FW 296.44, tetragonal, $\mathrm{P}_{1} 2_{1} 2$, $\mathrm{Z}=4, a=b=10.816(4), c=14.978(10) \AA, \mathrm{V}=1752.3(14) \AA^{3}, \mathrm{wR}_{2}$ (all 1773 data $)=0.108, \mathrm{R}_{1}[1674$ data with $\mathrm{I}>2 \sigma(\mathrm{I})] 0.038 ; \mathbf{5}: \mathrm{C}_{20} \mathrm{H}_{28} \mathrm{AgN}_{3} \mathrm{O}_{4}$, FW 482.32, orthorhombic, $\mathrm{P} 2{ }_{1} 2_{2} 2_{1}, \mathrm{Z}=8, a=13.721(4), b=14.368(4), c$ $=22.876(6) \AA, \mathrm{V}=4510(2) \AA^{3}$, Flack parameter -0.06(3), $\mathrm{wR}_{2}$ (all 9154 185 data) $=0.120, \mathrm{R}_{1}[6966$ data with $\mathrm{I}>2 \sigma(\mathrm{I})] 0.042 ; \mathbf{6}: \mathrm{C}_{26} \mathrm{H}_{30} \mathrm{Ag}_{2} \mathrm{~N}_{6} \mathrm{O}_{8}, \mathrm{FW}$ 770.30 , orthorhombic, $\mathrm{P} 2{ }_{1} 2{ }_{1} 2, \mathrm{Z}=2, a=7.368(3), b=28.931(10), c=$ 7.214(2) $\AA, V=1537.8(9) \AA^{3}$, Flack parameter 0.13(9), $w_{2}$ (all 3069 data) $=0.156, \mathrm{R}_{1}[2571$ data with $\mathrm{I}>2 \sigma(\mathrm{I})]$ 0.056. CCDC 611660-611662. For crystallographic data in CIF or other electronic format see DOI: $19010.1039 / b 000000 x$

1 (a) M. Munakata, L. P. Wu and T. Kuroda-Sowa, Adv. Inorg. Chem., 1999, 46, 173-303; (b) A. N. Khlobystov, A. J. Blake, N. R. Champness, D. A. Lemenovskii, A. G. Majouga, N. V. Zyk and M. Schröder, Coord. Chem. Rev., 2001, 222, 155-192; (c) S.-L. Zheng, M.-L. Tong and X.-M. Chen, Coord. Chem. Rev., 2003, 246, 185202; (d) C.-L. Chen, B.-S. Kang and C.-Y. Su, Aust. J. Chem., 2006, 59, 3-18.

2 (a) P. J. Hagrman, D. Hagrman and J. Zubieta, Angew. Chem., Int. $200 \quad$ Ed., 1999, 38, 2638-2684; (b) D. Braga, F. Grepioni and G. R. Desiraju, Chem. Rev., 1998, 98, 1375-1406; (c) S. R. Batton, Curr. Opin. Solid State Mater. Sci., 2001, 5, 107-114; (d) M. W. Hosseini, Acc. Chem. Res., 2005, 38, 313-323.

3 (a) C. Janiak, Dalton Trans., 2003, 2781-2803; (b) G. S.

205 Papaefstathiou and L. R. MacGillivray, Coord. Chem. Rev., 2003, 246, 169-184; (c) B. Kesanli and W. Lin, Coord. Chem. Rev., 2003, 246, 305-326; (d) S. Kitagawa, R. Kitaura and S. Noro, Angew. Chem., Int. Ed., 2004, 43, 2334-2375.

4 (a) O.R. Evans and W. Lin, Acc. Chem. Res., 2002, 35, 511-522; (b)

210 O. Maury and H. Le Bozec, Acc. Chem. Res., 2005, 38, 691-704.

5 P. J. Steel, Acc. Chem. Res., 2005, 38, 243-250.

6 A. Jouaiti, M. W. Hosseini and N. Kyritsakas, Chem. Commun., 2002, 1898-1899.
7 C. M. Fitchett and P. J. Steel, New J. Chem., 2000, 24, 945-947.

2158 H. Rupe and A. T. di Vignano, Helv. Chim. Acta, 1937, 20, 10971117.

9 M. A. M. Abu-Youssef, V. Langer and L. Öhrström, Dalton Trans., 2006, 2542-2550.

10 (a) F. H. Allen, Acta Crystallogr., Sect. B, 2002, 58, 380-388; (b) F. H. Allen and W. D. S. Motherwell, Acta Crystallogr., Sect. B, 2002, 58, 407-422; (c) F. H. Allen and R. Taylor, Chem. Soc. Rev., 2004, 33, 463-475.

11 (a) A. Démaret and F. Abraham, Acta Crystallogr., Sect. C, 1987, 43, 1519-1521; (b) K. Nomiya, S. Takahashi, R. Noguchi, S. Nemoto, T. Takayama and M. Oda, Inorg. Chem., 2000, 39, 3301-3311; (c) K. Nomiya, S. Takahashi and R. Noguchi, J. Chem. Soc., Dalton Trans., 2000, 4369-4373; (d) K. Nomiya and H. Yokohama, J. Chem. Soc., Dalton Trans., 2002, 2483-2490.

12 (a) W. Lewis and P. J. Steel, Supramolecular Chem., 2005, 17, 579584; (b) G. Meyer, A. Berners and I. Pantenburg, Z. Anorg. Allg. Chem., 2006, 632, 34-35.

13 There is slight disorder in the position of the silver atom, with a second (13\% occupancy) component not shown. Similar disorder was found in the previously reported complex of ligand $\mathbf{1}^{7}$ 